\title{
Flora of Espírito Santo: Dennstaedtiaceae
}

\author{
Pedro B. Schwartsburd ${ }^{1,2}$
}

\begin{abstract}
As part of the Flora of Espírito Santo project, it is presented the taxonomic treatment of Dennstaedtiaceae, with keys, descriptions, illustrations, and list of specimens examined. In this state (and adjacent areas of Minas Gerais), eleven taxa of Dennstaedtiaceae were found: Blotiella lindeniana, Dennstaedtia cicutaria, Dennstaedtia cornuta, Dennstaedtia globulifera, Histiopteris incisa, Hypolepis acantha, Hypolepis mitis, Hypolepis rigescens var. rigescens, Hypolepis rugosula subsp. pradoana, Pteridium arachnoideum subsp. arachnoideum, and Pteridium arachnoideum subsp. campestre. Most of these taxa are widespread along the Neotropics, but three (or four) are endemic to the Brazilian Atlantic Rainforest: Hypolepis acantha, Hypolepis mitis, and Hypolepis rugosula subsp. pradoana (and possibly Dennstaedtia cornuta).

Key-words: Dennstaedtia, Hypolepis, large ferns, Pteridium, Southeastern Brazil.

\section{Resumo}

Como parte do projeto Flora do Espírito Santo, aqui é apresentado o tratamento taxonômico de Dennstaedtiaceae, contendo chaves de identificação, descrições, ilustrações e lista de espécimes examinados. Neste estado (e áreas adjacentes em Minas Gerais) ocorrem onze táxons de Dennstaedtiaceae: Blotiella lindeniana, Dennstaedtia cicutaria, Dennstaedtia cornuta, Dennstaedtia globulifera, Histiopteris incisa, Hypolepis acantha, Hypolepis mitis, Hypolepis rigescens var. rigescens, Hypolepis rugosula subsp. pradoana, Pteridium arachnoideum subsp. arachnoideum e Pteridium arachnoideum subsp. campestre. A maioria destes táxons são amplamente distribuídos na região neotropical, porém três (ou quatro) são endêmicos à Floresta Atlântica brasileira: Hypolepis acantha, Hypolepis mitis e Hypolepis rugosula subsp. pradoana (e possivelmente Dennstaedtia cornuta).
\end{abstract}

Palavras-chave: Dennstaedtia, Hypolepis, samambaias grandes, Pteridium, Sudeste do Brasil.

\section{Introduction}

Dennstaedtiaceae is a medium sized, subcosmopolitan family of ferns with ca. 10-15 genera, and ca. 250-270 species (Tryon \& Tryon 1982; Kramer 1990; Smith et al. 2008; Schwartsburd \& Prado 2015; PPG I 2016). As currently circumscribed, Dennstaedtiaceae is monophyletic - i.e., with the exclusion of Saccoloma (Saccolomataceae), Lonchitis (Lonchitidaceae), and Odontosoria, Lindsaea and its allied genera (Lindsaeaceae) (Wolf 1995; Smith et al. 2008; Perrie et al. 2015; PPG I 2016). Dennstaedtiaceae is mostly recognized by the long-creeping rhizomes, clothed with multicellular hairs, large leaves (to 10 $\mathrm{m}$ long in some species), bipinnate to pentapinnate laminae, absence of true scales, and sub-marginal to marginal sori.
In this family, Pteridium, the bracken fern (samambaia-do-campo), has negative economical importance due to its ability to invade croplands and to its toxicity to cattle, horses, and mankind (Tryon 1941; Hojo-Souza et al. 2010; Schwartsburd et al. 2014). Pteridium is present in almost every country of the world. The other genera of Dennstaedtiaceae are composed of harmless forest-dwelling species, with Hypolepis, Dennstaedtia, and Microlepia with the greatest richness of species (Tryon 1960; Tryon \& Tryon 1982; Kramer 1990; Navarrete \& Ølgaard 2000; Mickel \& Smith 2004; Schwartsburd \& Prado 2014, 2015, 2016; Schwartsburd et al. 2016).

For the project Flora of Espírito Santo, it is here presented the updated taxonomic treatment of this family.

\footnotetext{
${ }^{1}$ Universidade Federal de Viçosa, Depto. Biologia Vegetal, Av. P.H. Rolfs s/n, 36570-900, Viçosa, MG, Brazil.

${ }^{2}$ Author for correspondence: pedro.schw@ufv.br
} 


\section{Material and Methods}

For this Flora, I visited the following herbaria: CESJ, MBML, RB, UPCB, VIC, and VIES. $\mathrm{BHCB}$ was consulted online. Some types were studied during a trip to Europe in 2010, and others by high quality images available online, from: herbarium B (<http://ww2.bgbm.org/herbarium/ default.cfm $>$ ), herbarium $\mathrm{S}(<$ http://herbarium. nrm.se/ $>$ ), herbarium US (<http://collections. nmnh.si.edu/search/botany/?ti=3 $>$ ), JStor Global Plants (<https://plants.jstor.org/collection/ TYPSPE $>$ ), and Reflora (<http://reflora.jbrj.gov. br/reflora/herbarioVirtual/ConsultaPublicoHVUC/ ConsultaPublicoHVUC.do $>$ ).

I also collected Dennstaedtiaceae specimens in the following localities in Espírito Santo and adjacent areas: Parque Nacional Serra do Caparaó (Espírito Santo and adjacent part of Minas Gerais), Parque Estadual Mata das Flores, RPPN Mata do Sossego (adjacent part of Minas Gerais), APA Pedra do Elefante, around Domingos Martins, and in a conserved patch of white sand forest (Restinga) between Vila Velha and Ponta da Fruta.

Reinaldo Pinto made the drawings of Figures $1 ; 2 ; 3 ; 4 d, e ; 5 a-d ; 6$. Kley Souza made the drawings of Figures $4 \mathrm{a}-\mathrm{c}, \mathrm{f}-\mathrm{i} ; 5 \mathrm{e}-\mathrm{h}$.

\section{Results and Discussion}

In the state of Espírito Santo and adjacent areas of Minas Gerais, eleven taxa of Dennstaedtiaceae belonging to five genera occur: Blotiella lindeniana (Hook.) R.M.Tryon, Dennstaedtia cicutaria (Sw.) T.Moore, Dennstaedtia cornuta (Kaulf.) Mett., Dennstaedtia globulifera (Poir.) Hieron, Histiopteris incisa (Thunb.) J.Sm., Hypolepis acantha Schwartsb., Hypolepis mitis Kuhn, Hypolepis rigescens (Kunze) T.Moore var. rigescens, Hypolepis rugosula subsp. pradoana Schwartsb., Pteridium arachnoideum (Kaulf.) Maxon subsp. arachnoideum, and Pteridium arachnoideum subsp. campestre (Schrad.) Schwartsb. \& P.L.R.Moraes. Most of these taxa are widespread along the Neotropics, but three are endemic to the Brazilian Atlantic Rainforest: Hypolepis acantha, Hypolepis mitis, and Hypolepis rugosula subsp. pradoana. The geographical distribution of Dennstaedtia cornuta is still uncertain and controversy, and it may be shown in the future that it is also endemic to the Brazilian Atlantic Rainforest.

It is possible that a few more species may also occur in the state, due to their records on surrounding states. They are: Dennstaedtia dissecta T.Moore, Hypolepis repens (L.) C.Presl, Microlepia speluncae (L.) T.Moore, and Paesia glandulosa (Sw.) Kuhn. These species are not included in the taxonomic treatment, but they are included in the keys (with an asterisk “*”), for future references.

\section{Dennstaedtiaceae}

Plants terrestrial, rarely epiphytic or epipetric. Rhizomes generally long-creeping and dorsiventral, rarely ascending and radial, generally solenostelic, glabrous or clothed with multicellular cells, rarely also with proscales. Fronds monomorphic, not articulated to the rhizomes, commonly large, to $10 \mathrm{~m}$ long, generally determinate, rarely with intermittent growth; petioles generally adaxially grooved, commonly aculeate; laminae bipinnate to pentapinnate, rarely less dissected; veins free or anastomosing without included veinlets; indument commonly formed by multicellular hairs and/or glandular hairs, scales absent; receptacle formed on commissural veins or on the tip of single veins; sori sub-marginal or marginal, linear, elongate, or discrete and roundish, rarely unprotected, generally protected by true abaxial indusia, pseudoindusia, or fusion among true indusia and pseudoindusia; sporangia with vertical annulus, interrupted by the pedicel; spores monolete or trilete.

Circa 10 to 15 genera, and 250 to 270 species worldwide (Tryon \& Tryon 1982; Kramer 1990; Smith et al. 2008; Schwartsburd \& Prado 2015; PPG I 2016).

\section{Key to genera of Dennstaedtiaceae from the state of Espírito Santo}

1. Veins anastomosing (e.g., Fig. 1f,1).

2. Laminae glabrous; sori along segment margins. 3. Histiopteris (Histiopteris incisa)

2'. Laminae pilose; sori in sinuses between segments 1. Blotiella (Blotiella lindeniana)

1'. Veins free.

3. Sori elongate to linear, born on vascular commissures.

4. Laminae glandular; sori along segment margins, interrupted in the sinuses 
4'. Laminae eglandular; sori continuous, along segment margins and sinuses................ 5. Pteridium

3'. Sori discrete, roundish, born on the tip of single veins.

5. Sori protected by true abaxial indusia fused to the pseudoindusia (e.g., Fig. 2g) ......2. Dennstaedtia

5'. Sori unprotected, protected by pseudoindusia (recurved laminar margin), or by true abaxial indusia.

6. Sori protected by true abaxial indusia... Microlepia (Microlepia speluncae)*

6'. Sori unprotected or protected by pseudoindusia (e.g., Figs. 4h; 5g)...... 4. Hypolepis

1. Blotiella R.M.Tryon, Contr. Gray Herb. 191: 96. 1962.

Rhizomes ascending, dictyostelic, with ciliform or catenate hairs. Fronds with determinate growth; petioles adaxially grooved, inermous; laminae bipinnate or bipinnate-pinnatifid; rachises straight; basal pinnae equilateral; costae without decurrent adaxial wings; veins anastomosing; laminar indument of long ciliform hairs; sori marginal, elongate, along the sinuses, protected by pseudoindusia; spores monolete.

Circa 20 species mostly in Africa, with only one in the Americas (Tryon 1962; Tryon \& Tryon 1982; Kramer 1990; PPG I 2016).

1.1. Blotiella lindeniana (Hook.) R.M.Tryon, Contr. Gray Herb. 191: 99. 1962. Lonchitis lindeniana Hook., Sp. Fil. 2: 56, t. 89a. 1858 [May 1851]. Pteris lindeniana (Hook.) Christ in Pittier, Prim. Fl. Costaric. 3: 22. $1901 . \quad$ Fig. 1a-f Plants terrestrial. Rhizomes ascending to erect, to $30 \mathrm{~cm}$ tall, with brown catenate hairs. Fronds determinate, prostrate, $2-3 \mathrm{~m}$ long; petioles dark brown proximally, lighter brown above, densely pilose, with long, reddish ciliform hairs; laminae bipinnate-pinnatifid proximally; rachises straight, light brown to stramineous, densely pilose; basal pinnae 15-40 × 10-20 cm, equilateral; costae abaxially and adaxially densely pilose, with long, whitish and reddish, ciliform hairs; costules abaxially and adaxially with whitish ciliform hairs; veins anastomosing, abaxially and adaxially with whitish ciliform hairs, and a few catenate-glandular hairs; laminar tissue between the veins abaxially and adaxially with whitish ciliform hairs, and a few catenate-glandular hairs; lamina margins densely ciliate; pseudoindusia densly pilose and ciliate.

Specimens examined: Castelo, Braço do Sul, 17.VIII.1948, A.C. Brade 19313 (RB), Parque Estadual do Forno Grande, 2031'37'S, 41 ${ }^{\circ} 06^{\prime} 06^{\prime}$ 'W, 1250 m, 13.II.2008, P.H. Labiak et al. 4584 (CEPEC-n.v., MBML, NY-n.v., RB, SP-n.v., UPCB-n.v.); Limoeiro, Santa Maria, 17.V.1946, A.C. Brade et al. 18285 (RB). Santa Teresa, Nova Lombardia, Reserva Biológica Augusto Ruschi, 1951'26”'S, 40³3'14'W, 780-870 m, 25.II.2003, R.R. Vervloet et al. 1913 (MBML).
Additional specimens examined: BRAZIL. MINAS GERAIS [near the border of ESPÍRITO SANTO]: Simonésia, RPPN Mata do Sossego, $20^{\circ} 03^{\prime} \mathrm{S}, 42^{\circ} 02^{\prime} \mathrm{W}$, ca. 1000 m, 19.IX.2014, P.B. Schwartsburd et al. 3348 (MBML, VIC, VIES), 20.IX.2014, P.B. Schwartsburd et al. 3401 (RB, SP, VIC), P.B. Schwartsburd et al. 3414 (NY, VIC).

Blotiella is a primarily African genus, with only $B$. lindeniana occurring in the Neotropics (Tryon 1962; Tryon \& Stolze 1989; Prado et al. 2015). Although widely distributed throughout the Neotropics, B. lindeniana is rare in nature (Tryon \& Stolze 1989, personal observation). In the state of Espírito Santo it occurs from 780 to $1250 \mathrm{~m}$ a.s.l., inside forests and cloud forests (Matas Nebulares).

Blotiella lindeniana is easily characterized by the ascending to erect rhizomes, long reddish ciliform hairs on petioles and rachises, whitish ciliform hairs on costae and costules, anastomosing veins, elongate marginal sori along the sinuses, and the presence of pseudoindusia (true indusia absent) (Fig. 1a-f).

2. Dennstaedtia Bernh., J. Bot. (Schrader) 1800(2): 124. 1801.

Rhizomes short to long-creeping, solenostelic or with a polycyclic solenostele, glabrous or with catenate hairs. Fronds with determinate growth; petioles adaxially grooved, with or without buds at base, inermous or rarelly aculeate; laminae rarely 1-pinnate, generally 2-pinnate-pinnatifid or more dissected; rachises straight, with or without buds; basal pinnae equilateral; costae adaxially with or without decurrent wings; veins free; laminar indument of catenate hairs, acicular hairs, or absent; sori, marginal, discrete and roundish, at the tip of single veins, protected by pseudoindusia and true abaxial indusia fused into cup shaped indusia; spores trilete.

As currently circumscribed, Dennstaedtia is paraphyletic, with some species nesting with Microlepia, and others on a separate clade (Perrie et al. 2015; PPG I 2016). Although the soral types are similar among the clades of Dennstaedtia, Becari-Viana \& Schwartsburd (2017) showed there 


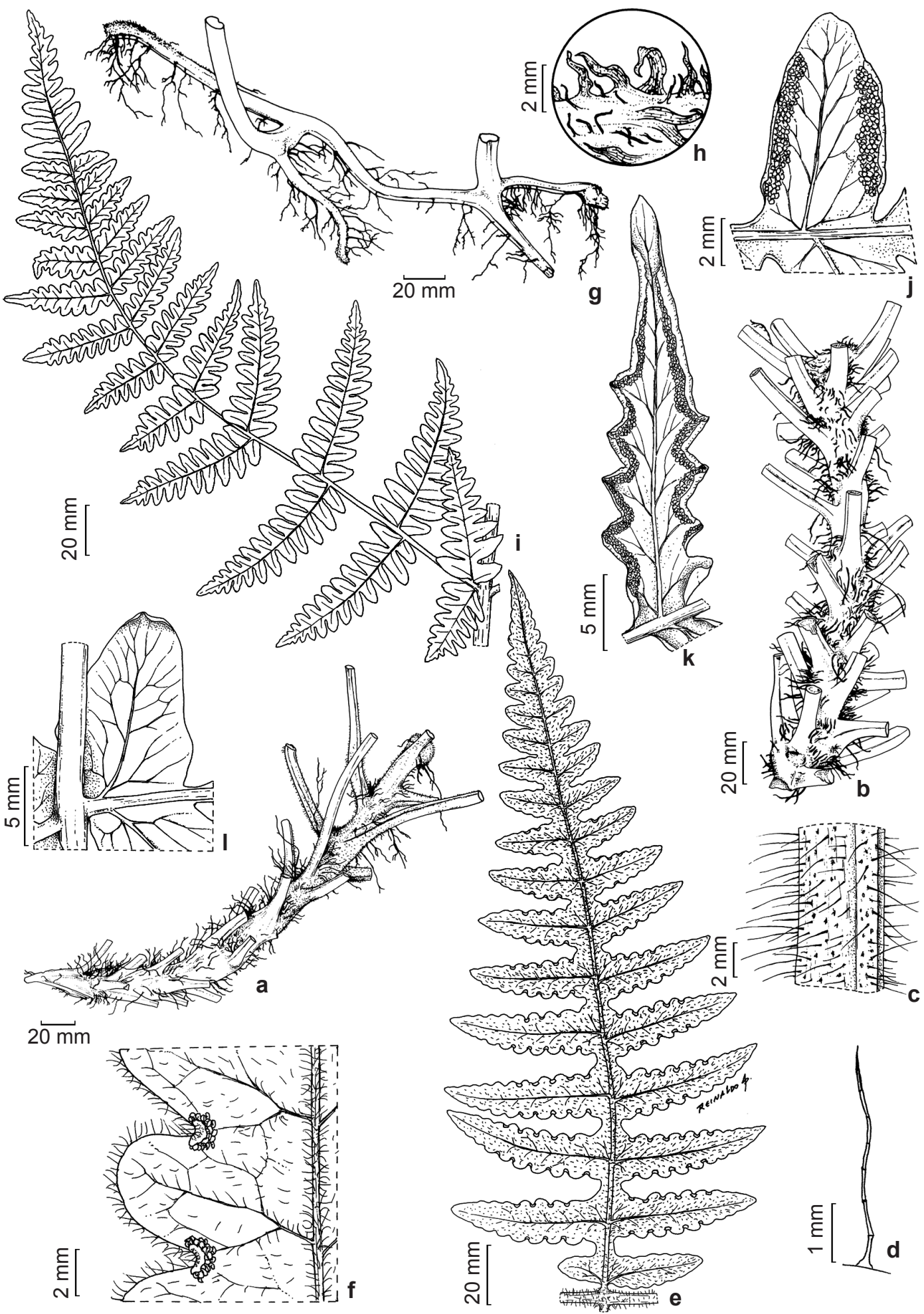

Figure 1 - a-f. Blotiella lindeniana - a. ascending rhizome; b. erect rhizome; c. section of the petiole; d. hair from petiole; e. basal pinna; f. segment, abaxially. g-l. Histiopteris incisa - g. rhizome; h. detail of proscales and hairs on the rhizome; i. basal pinna; j. segment, abaxially; k. pinnule, abaxially; 1. acessory segment, abaxially. (a-f. Schwartsburd 3401; g-1. Schwartsburd 2297) 
are substantial differences in their stele types. As currently circumscribed Dennstaedtia has circa 70 species (PPG I 2016); in the state of Espírito Santo three species occur, and possibly another one.

\section{Key to species of Dennstaedtia from the state of Espírito Santo}

1. Pinna-rachises with adaxial wings continuous onto costae; costae with adaxial wings continuous onto costules (Fig. 2f) 2.3. Dennstaedtia globulifera

1'. Pinnae-rachises and costae without adaxial continuous wings.

2. Laminar tissue between the veins abaxially hirsute, with erect, acicular hairs (Fig. 2c).

2'. Laminar tissue between the veins abaxially glabrous.

3. Rhizomes long-creeping, horizontal, pilose; rachises without buds ......Dennstaedtia dissecta*

3'. Rhizomes short-creeping to ascending, glabrous (Fig. 3a); rachises commonly with buds ... 2.2. Dennstaedtia cornuta

2.1. Dennstaedtia cicutaria (Sw.) T.Moore, Index Fil. xcvii. 1857. Dicksonia cicutaria Sw., J. Bot. (Schrader) 1800(2): 91. 1801.

Fig. 2a-c

Plants terrestrial. Rhizomes long-creeping, with brownish catenate hairs or glabrescent. Fronds determinate, prostrate, $1-2 \mathrm{~m}$ long; petioles brown proximally, lighter brown above, with scattered acicular hairs on the groove; laminae tripinnatepinnatifid to tetrapinnate proximally; rachises straight, light brown, hirsute, with erect, acicular hairs, without buds; basal pinnae 30-60 × 20-35 $\mathrm{cm}$, subequilateral; pinna-rachises and costae without continuous adaxial wings; costae abaxially and adaxially pilose, with reddish catenate-acicular hairs; costules abaxially and adaxially pilose, with reddish catenate-acicular hairs; veins abaxially and adaxially hirsute, with erect, acicular hairs; laminar tissue between the veins abaxially and adaxially with scattered acicular hairs; lamina margins glabrous; indusia elongate, purse-shaped, commonly with a few acicular hairs.

Specimens examined: Itaguaçu, Alto Limoeiro, Santa Maria, 23.V.1946, A.C. Brade et al. 18371 (MO-n.v., RB).

Dennstaedtia cicutaria is widespread in the Neotropics (Navarrete \& Øllgaard 2000; Mickel \& Smith 2004; Prado et al. 2015). In the state of Espírito Santo it occurs at ca. 100-700 m a.s.l., in clearings and edges of forests.

Dennstaedtia cicutaria is easily recognized by the erect, acicular hairs present on veins, laminar tissue between the veins, and in the purse-shaped indusia (Fig. 2a-c).

2.2. Dennstaedtia cornuta (Kaulf.) Mett., Ann. Sci. Nat. V, 2: 260. 1864. Dicksonia cornuta Kaulf., Enum. Fil. 227. 1824.

Fig. 3a-d
Plants terrestrial. Rhizomes short-creeping to ascending, glabrous. Fronds determinate, prostrate 1.5-2(-2.5) $\mathrm{m}$ long; petioles dark brown proximally, lighter brown above, with catenate hairs; laminae bipinnate-pinnatifid to tripinnatepinnatifid proximally; rachises straight, light brown to stramineous, with catenate hairs, commonly with buds; basal pinnae 25-50 × 7-15 cm, equilateral; pinna-rachises and costae without continuous adaxial wings; costae abaxially and adaxially pilose, with catenate hairs; costules abaxially pilose, adaxially glabrescent, with catenate hairs; veins abaxially and adaxially glabrescent; laminar tissue between the veins abaxially and adaxially glabrous; lamina margins glabrous; indusia hemispherical, glabrous.

Specimens examined: Cariacica, Alegre, $20.2642^{\circ} \mathrm{S}$, $40.4197^{\circ} \mathrm{W}, 24 . \mathrm{VI} .1988$, O.L. Pereira et al. 1558 (VIC, VIES), Reserva Biológica Duas Bocas, 20¹7'29"S, 40³1'10"W, 600 m, 15.II.2008, P.H. Labiak et al. 4618 (CEPEC-n.v., MBML, RB, UPCB-n.v.). Castelo, Parque Estadual Forno Grande, $20^{\circ} 30^{\prime} 58^{\prime \prime}$ 'S, $41^{\circ} 06^{\prime} 41^{\prime \prime} \mathrm{W}, 1500$ m, 19 VII.2008, P.H. Labiak et al. 4846 (CEPEC-n.v., MBML, RB, UPCB-n.v.). Santa Maria de Jetibá, Rio Nove, 730 m, 28.XII.2007, L. Kollmann 10271 (MBML). Santa Teresa, Nova Lombardia, Reserva Biológica Augusto Ruschi, 800 m, 3.X.2002, R.R. Vervloet 1132 (MBML).

Additional specimens examined: BRAZIL. MINAS GERAIS [near the border of ESPÍRITO SANTO]: Alto Caparaó, Parque Nacional Serra do Caparaó, 20²9'44"S, 41 ${ }^{\circ} 49^{\prime} 12^{\prime}$ 'W, $1500 \mathrm{~m}, 12 . I I I .2014$, P.B. Schwartsburd \& J.B.S. Pereira 3140 (VIC), P.B. Schwartsburd \& J.B.S. Pereira 3142 (VIC), Vale Verde, 1100 m, 29.IX.1977, L. Krieger (VIC-5806 [on 2 sheets]). Simonésia, RPPN Mata do Sossego, $20^{\circ} 03^{\prime} \mathrm{S}, 42^{\circ} 02^{\prime} \mathrm{W}$, ca. $1000 \mathrm{~m}$, 19.IX.2014, P.B. Schwartsburd et al. 3355 (RB, VIC), P.B. Schwartsburd et al. 3357 (VIC). 
The Dennstaedtia dissecta-complex is confusing, in need of a modern revision, and has been differently treated by some authors. Tryon (1960), for example, accepted D. dissecta (Sw.) T.Moore and D. obtusifolia (Willd.) T.Moore for the Americas, but he later (Tryon \& Stolze 1989) synonymyzed $D$. obtusifolia under $D$. dissecta. On the other hand, Navarrete \& Øllgaard (2000) accepted $D$. dissecta and D. obtusifolia (with different circumscriptions), plus $D$. auriculata Navarr. \& B.Øllg., D. cornuta (Kaulf.) Mett. (type from S/SE Brazil), and D. tryoniana Navarr. \& Øllg. Assis \& Salino (2011) apparently followed the proposal of Navarrete \& Ølgaard (2000), and accepted $D$. dissecta and $D$. cornuta in the state of Minas Gerais. Schwartsburd (2010) and Prado et al. (2015), however, returned to the circumscription of Tryon (1960).

In Southern and Southeastern Brazil, I am able to recognize two species from this complex. I here provisionally adopt the names Dennstaedtia disssecta and $D$. cornuta, but with a different circumscription than that of Assis \& Salino (2011). Dennstaedtia cornuta is the only one that have been collected in Espírito Santo so far, and it is characterized by short-creeping to ascending, glabrous rhizomes, bipinnate-pinnatifid to tripinnate-pinnatifid laminae, and rachises commonly with buds (Fig. 3a-d). On the other hand, $D$. dissecta has long-creeping, pilose rhizomes, tripinnate-pinnatifid to tetrapinnate laminae, and rachises lacking buds.

Until the Dennstaedtia dissecta-complex is reviewed, it is difficult to establish the real geographical distribution of its taxa. Navarrete \& Øllgaard (2000) and Mickel \& Smith (2004) cited D. cornuta as occurring throughout the Neotropics, and not in Brazil, but this is an error, since its type is from Brazil. I suspect $D$. cornuta may be actually endemic to the Brazilian Atlantic Rainforest. In the state of Espírito Santo, it occurs from 600 to $1500 \mathrm{~m}$ a.s.l., in forests and cloud forests (Matas Nebulares).

2.3. Dennstaedtia globulifera (Poir.) Hieron., Bot. Jahrb. Syst. 34(4): 455. 1904. Polypodium globuliferum Poir. in Lam., Encycl. [J. Lamarck et al.] 5: 554. 1804. Dicksonia globulifera (Poir.) Kuntze, Revis. Gen. Pl. 3(3): 378. 1898. Dicksonia altissima Sm. in Rees, Cycl. 11. 1808, nom. nov. et stat. nov. pro Polypodium globuliferum.

Fig. 2d-g

Plants terrestrial. Rhizomes long-creeping, with brownish catenate hairs. Fronds determinate, prostrate, $1.5-2.5 \mathrm{~m}$ long; petioles stramineous to light brown, glabrescent, with sparse brownish catenate hairs; laminae tripinnate-pinnatifid proximally; rachises straight, stramineous to light brown, with sparse catenate hairs, without buds; basal pinnae 35-45 × 15-25 cm, equilateral; pinna-rachises with adaxial wings continuous onto costae, and costae with adaxial wings continuous onto costules; costae abaxially pilose, with hyaline catenate hairs, adaxially glabrous; costules abaxially pilose, with hyaline catenate hairs, adaxially glabrous; veins abaxially pilose, with hyaline catenate hairs, adaxially glabrous; laminar tissue between the veins abaxially with scattered catenate hairs, adaxially glabrous; lamina margins glabrous; indusia hemi-spherical to tubular, pilose.

Specimens examined: Castelo, Parque Estadual Mata das Flores, $20^{\circ} 35^{\prime} \mathrm{S}, 41^{\circ} 10^{\prime} \mathrm{W}, 400 \mathrm{~m}, 2 . \mathrm{III} .2016$, P.B. Schwartsburd et al. 3702 (VIC), 3 III.2016, P.B. Schwartsburd et al. 3715 (VIC, VIES).

Dennstaedtia globulifera is widespread in the Neotropics (Navarrete \& Øllgaard 2000; Mickel \& Smith 2004; Prado et al. 2015); in the state of Espírito Santo it occurs inside lowland forests (ca. $400 \mathrm{~m}$ a.sl.).

Dennstaedtia globulifera differs from the other Dennstaedtia of Espírito Santo by pinna-rachises with adaxial wings continuous onto costae and costae with adaxial wings continuous onto costules (Fig. 2f). Such continuous wings are absent in the other species. Dennstaedtia globulifera is also characterized by long-creeping rhizomes, clothed with brownish catenate hairs, tripinnate-pinnatifid laminae, and hemi-spherical to tubular indusia (Fig. 2d-g).

3. Histiopteris (J.Agardh) J.Sm., Hist. Fil.: 294: 1875.

Rhizomes long-creeping, solenostelic, with catenate hairs and comose proscales. Fronds with determinate growth; petioles adaxially grooved, inermous; laminae bipinnate or more dissected, often glaucous; rachises straight; basal pinnae equilateral; costae without decurrent adaxial wings; veins anastomosing; laminar indument absent; sori marginal, linear, along segment margins, protected by pseudoindusia; spores monolete.

Circa seven species, with only one in the Americas (Tryon \& Tryon 1982; Kramer 1990; PPG I 2016).

3.1. Histiopteris incisa (Thunb.) J.Sm., Hist. Fil. 295. 1875. Pteris incisa Thunb., Prodr. Pl. Cap. 171. 1800. Litobrochia incisa (Thunb.) C.Presl, Tent. Pteridogr. 149. 1836.

Fig. 1g-1 


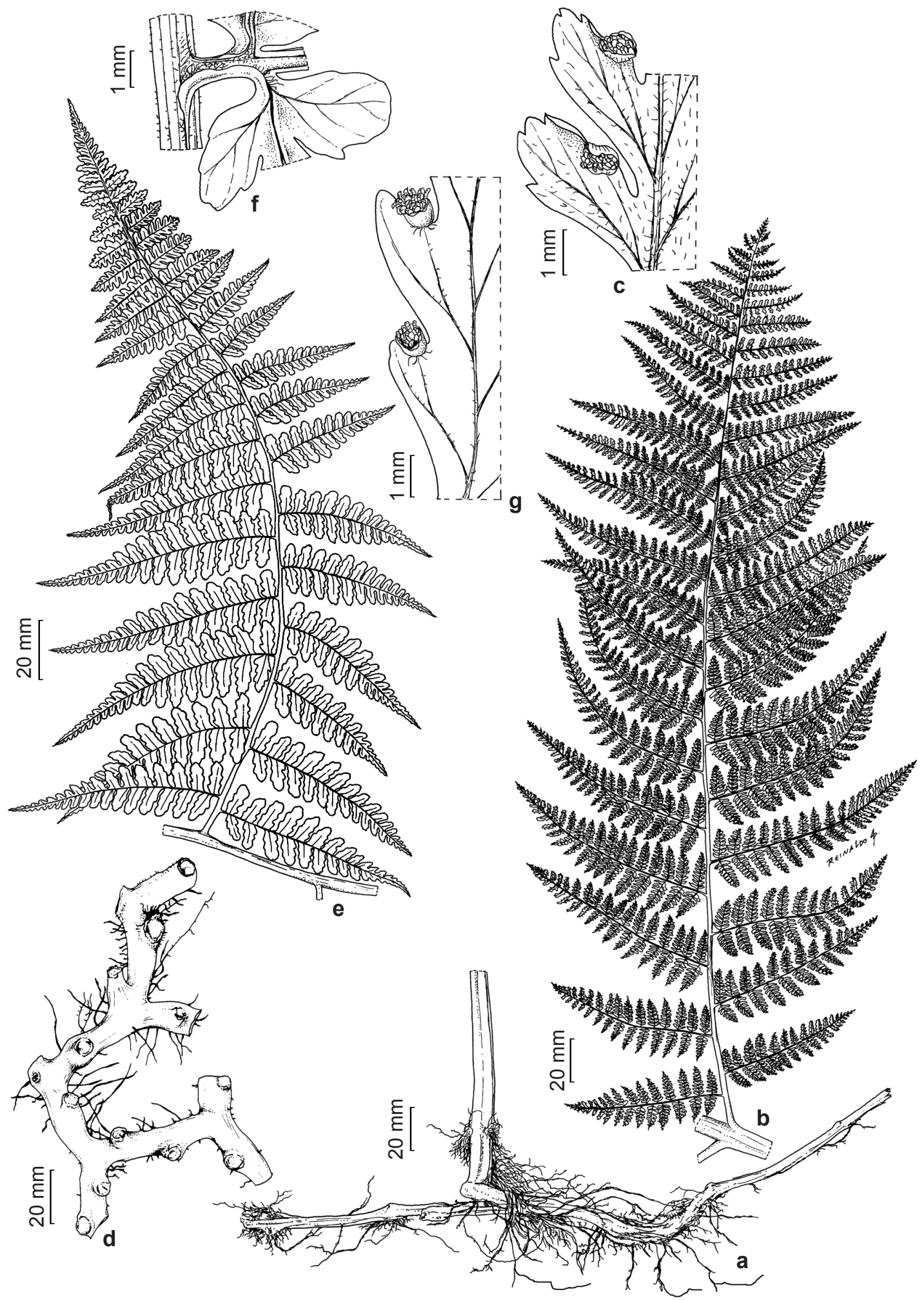

Figure 2 - a-c. Dennstaedtia cicutaria - a. rhizome; b. basal pinna; c. segments, abaxially. a-d. D. globulifera - d. rhizome; e. basal pinna; f. segment, adaxially, showing decurrent wing from pinnarachis to costa, and to costule; g. segments, abaxially. (a-c. Schwartsburd 3866; d. Schwartsburd 3069; e,g. Schwartsburd 2463; f. Yañez 91). 


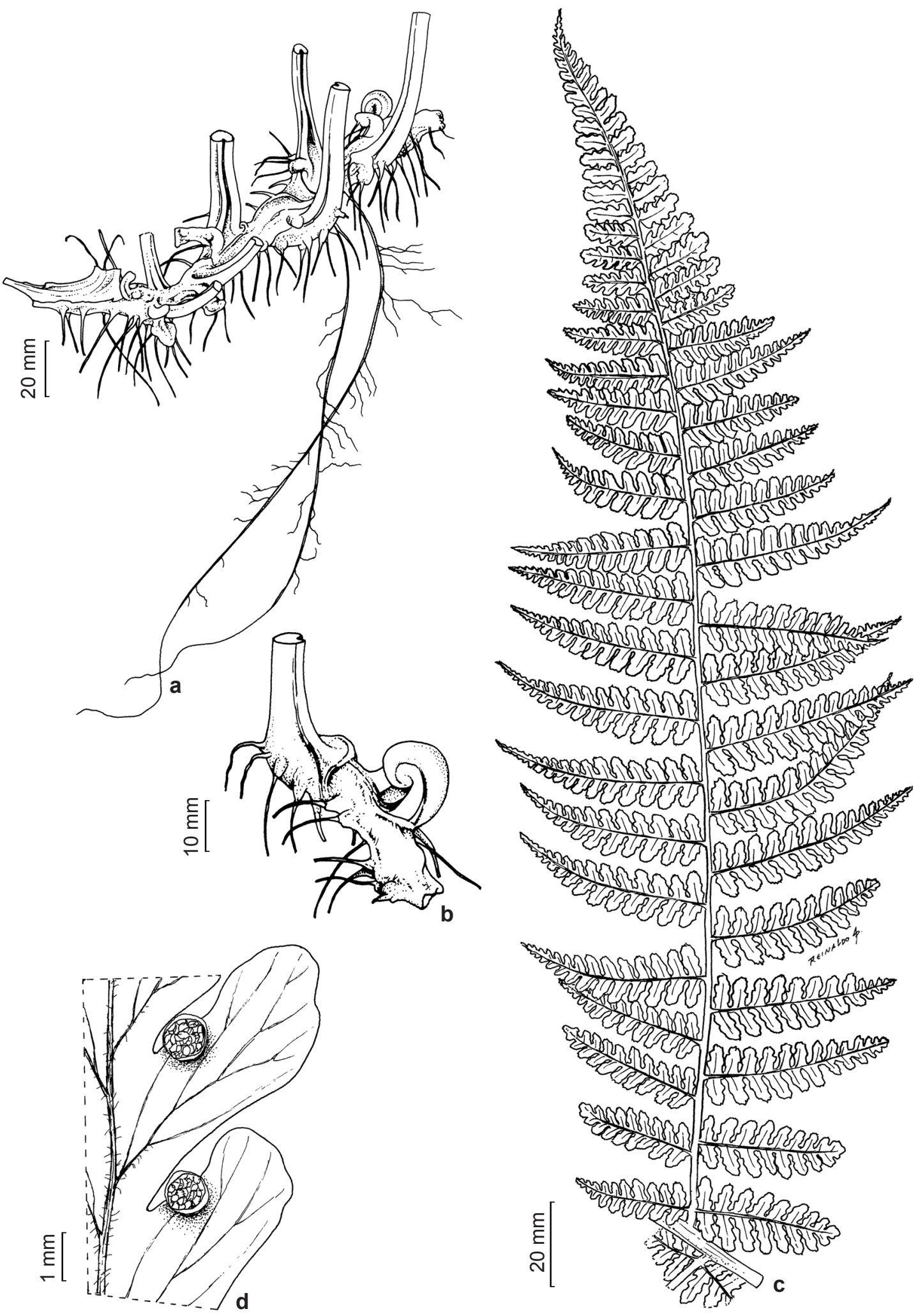

Figure 3 - a-d. Dennstaedtia cornuta - a. rhizome; b. detail of the rhizome; c. basal pinna; d. segments, abaxially. (a,b. Schwartsburd 3070; c,d. Schwartsburd 3355). 
Plants terrestrial. Rhizomes long-creeping, with brownish catenate hairs and brownish proscales. Fronds determinate, prostrate 1-2.5 $\mathrm{m}$ long; petioles purplish brown proximally, lighter brown above, glabrous; laminae bipinnatepinnatifid to tripinnate-pinnatifid proximally, commonly glaucous or pale green; rachises straight, light brown to stramineous, glabrous; basal pinnae 25-40 × 10-25 cm, equilateral; costae abaxially glabrous or rarely with scattered catenate hairs, adaxially glabrous; costules abaxially glabrous or rarely with scattered catenate hairs, adaxially glabrous; veins anastomosing, abaxially glabrous or rarely with scattered catenate hairs, adaxially glabrous; laminar tissue between the veins abaxially and adaxially glabrous; lamina margins glabrous; pseudoindusia elongate to linear, along the segment margins and sinuses, glabrous.

Specimens examined: Santa Teresa, Reserva Biológica de Nova Lombardia, 850 m, 20.II.2002, L. Kollmann 5611 (MBML-on 2 sheets).

Histiopteris incisa is a sub-cosmopolitan fern with a primary circum-Antarctic distribution (Mickel \& Smith 2004; Prado et al. 2015; Schwartsburd unpublished data); in the state of Espírito Santo it occurs inside Forests (ca. $850 \mathrm{~m}$ a.s.1.), and probably also at higher elevations in altitudinal fields (Campos de Altitude) and cloud forests (Matas Nebulares).
Histiopteris incisa is recognized by longcreeping rhizomes, clothed with brownish catenate hairs and brownish proscales, glaucous, glabrous laminae, anastomosing veins, and elongate to linear sori along the segment margins and sinuses, protected by pseudoindusia (Fig. 1g-1).

\section{Hypolepis Bernh., Neues J. Bot. 1(2): 34. 1805.}

Rhizomes long-creeping, solenostelic, with catenate-acicular hairs. Fronds determinate or with intermittent growth; petioles adaxially grooved, inermous or aculeate; laminae bipinnate to pentapinnate, rarely less dissected; rachises straight or flexuous; basal pinnae equilateral or commonly inequilateral; costae without or rarely with decurrent adaxial wings; veins free; laminar indument of acicular, catenate-acicular, glandular, or catenate-glandular hairs, and/or bacilliform or vermiform trichomidia; sori submarginal or marginal, discrete and roundish, in the sinuses, protected by a pseudoindusia, by the undifferentiated lamina margin, or not protected; spores monolete.

Circa 70-80 species, plus ca. 10-20 infraspecific taxa and hybrids (Schwartsburd \& Prado 2014, 2015, 2016; PPG I 2016; Schwartsburd et al. 2016). In the state of Espírito Santo four taxa occur, and possibly another one.

\section{Key to taxa of Hypolepis from the state of Espírito Santo}

1. Petioles and rachises inermous; sori unprotected or protected by recurved, untransformed laminar margins (Fig. 5g) 4.4. Hypolepis rugosula subsp. pradoana

1'. Petioles and rachises aculeate (e.g., Fig. 4b); sori protected by pseudoindusia (e.g., Fig. 4h).

2. Laminae glandular (glandular hairs present on laminar axes and laminar tissue between the veins) (Fig. 5c). 4.3. Hypolepis rigescens var. rigescens

2'. Laminae eglandular.

3. Petioles proximally purple; petioles and rachises sparsely aculeate and tuberculate

3'. Petioles proximally dark brown; petioles and rachises copiously aculeate.

4. Laminar tissue between the veins abaxially hirsute (Fig. 4c).....4.1. Hypolepis acantha

4'. Laminar tissue between the veins abaxially glabrous Hypolepis repens*

4.1. Hypolepis acantha Schwartsb., Kew Bull. 67(4): 816, Figs. 1a-c, 3a, b. $2012 . \quad$ Fig. 4a-c

Plants terrestrial. Rhizomes long-creeping with catenate-acicular hairs. Fronds determinate, scandent, (1.7-)3-6.5 m long; petioles dark brown proximally, lighter brown above, copiously aculeate, with trichomidia; laminae quadripinnate- pinnatifid proximally; rachises straight, light brown to brown, aculeate, with trichomidia; basal pinnae $55-105 \times 35-60 \mathrm{~cm}$, inequilateral; costae abaxially and adaxially pilose, the hairs catenate-acicular; costules abaxially pilose, adaxially sparsely pilose, with catenate-acicular hairs; veins abaxially pilose with catenate-acicular hairs, adaxially glabrous; 


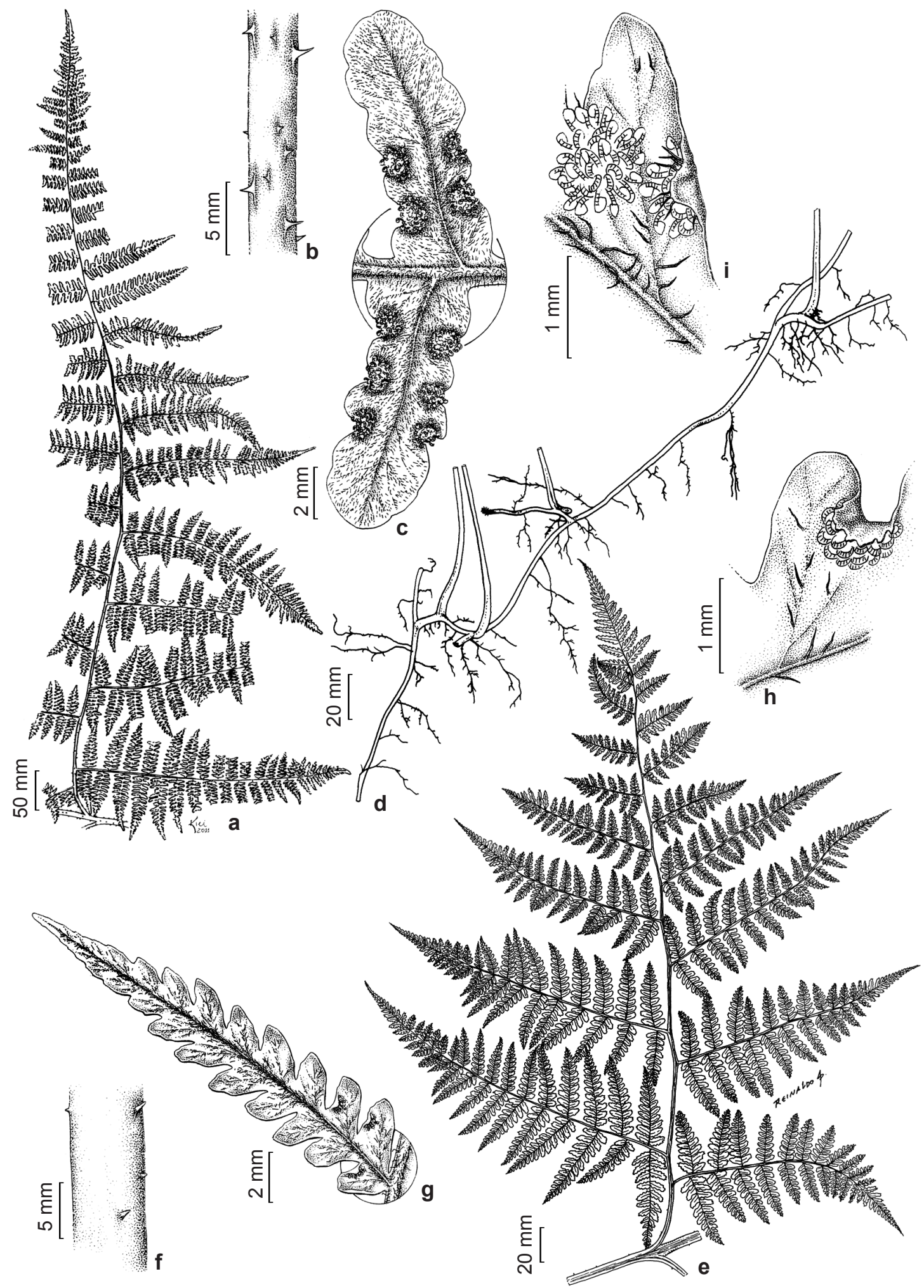

Figure 4 - a-c. Hypolepis acantha - a. basal pinna; b. section of the rachis; c. segments, abaxially. d-i. H. mitis - d. rhizome; e. basal pinna; f. section of petiole; g. pinnule, abaxially; h. segment, abaxially; i. segment, abaxially. (a-c. all from Schwartsburd 1344; d. Schwartsburd 3021; e. Labiak 4545; f,h,i. Schwartsburd 2317; g. Gardner 199). 
laminar tissue between the veins abaxially hirsute, the hairs acicular, erect, adaxially glabrous; lamina margins glabrous; sori marginal; pseudoindusia glabrous or rarely with one or two cilia.

Specimens examined: Linhares, Reserva Florestal de Linhares, Estrada do Louro, 1905'58'S, 4002'55'W, 30-60 m, 9.II.2007, T.E. Almeida et al. 687 (BHCB).

Hypolepis acantha is endemic to the Brazilian Atlantic Rainforest, in the states of Bahia, Espírito Santo, Rio de Janeiro, São Paulo, Paraná, and Rio Grande do Sul (Prado et al. 2015; Schwartsburd \& Prado 2015). In Espírito Santo it occurs in white sand forests (Restingas) and lowland forests to 60 $\mathrm{m}$ a.s.1.

Hypolepis acantha is easily recognized by the large fronds (to $6.5 \mathrm{~m}$ long), copiously aculeate petioles and rachises, and hirsute abaxial laminar tissue between the veins (Fig. 4a-c).

4.2. Hypolepis mitis Kunze ex Kuhn, Linnaea 36: 105. 1870.

Fig. 4d-i

Plants terrestrial. Rhizomes long-creeping with catenate-acicular hairs. Fronds determinate, arched to scandent, (0.75-)2-3.5 m long; petioles purple proximally, stramineous above, rugose, sparsely aculeate and tubeculate, with trichomidia; laminae quadripinnate to quadripinnate-pinnatifid proximally; rachises straight, greenish stramineous, sparsely aculeate and tuberculate, rugose, with trichomidia; basal pinnae (30-)50-70 × (25-)40-50 $\mathrm{cm}$, subequilateral; costae sparsely pilose abaxially and adaxially, the hairs catenate-acicular; costules sparsely pilose abaxially, glabrescent adaxially, with catenate-acicular hairs; veins sparsely pilose abaxially with catenate-acicular hairs, glabrous adaxially; laminar tissue between the veins abaxially sparsely strigose to glabrescent with catenate-acicular hairs, adaxially glabrous; lamina margins glabrous; sori marginal; pseudoindusia commonly with one or two cilia, rarely none or more.

Specimens examined: Castelo, Parque Estadual do Forno Grande, 20³0'58'S, 41 ${ }^{\circ} 05^{\prime} 01$ 'W, 1100 m, 12.II.2008, P.H. Labiak et al. 4545 (CEPEC-n.v., MBML, RB,

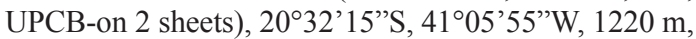
15.X.2008, P.H. Labiak et al. 4975 (CEPEC-n.v., MBML, RB-n.v., UPCB-n.v.).

Hypolepis mitis is endemic to the Brazilian Atlantic Rainforest, in the states of Minas Gerais, Espírito Santo, Rio de Janeiro, São Paulo, Paraná, and Rio Grande do Sul (Prado et al. 2015; Schwartsburd \& Prado 2015). In Espírito Santo it occurs at ca. 1100-1220 m a.s.l. in clearings, edge of forests, and altitudinal fields (Campos de Altitude).
4.3. Hypolepis rigescens (Kunze) T.Moore var. rigescens, Index Fil. (T. Moore) 11: 252. 1861. Cheilanthes rigescens Kunze in Mart., Flora 22(1), Beibl. 4: 51. 1839. Polypodium punctatum f. rigescens (Kunze) Baker in Mart. \& Eichler, Fl. bras. 1(2): 503, t. 65. $1870 . \quad$ Fig. 5a-c

Plants terrestrial. Rhizomes long-creeping with catenate-acicular hairs. Fronds determinate, erect to arched, 100-230 cm long; petioles purplish or rarely black proximally, golden-brown above, rugose, moderately aculeate, sparsely pilose to glabrescent with two kinds of hairs, catenate-acicular and catenate-glandular; laminae tripinnate-pinnatifid to quadripinnate proximally; rachises slightly curved at base, otherwise straight, golden-brown proximally, stramineous above, rugose, aculeate, sparsely pilose abaxially and adaxially, with catenate-acicular and catenateglandular hairs; basal pinnae $25-40 \times 12-25 \mathrm{~cm}$, subequilateral; costae pilose abaxially and adaxially, with catenate-acicular and catenate-glandular hairs; costules pilose abaxially, glabrescent adaxially, with catenate-acicular and catenate-glandular hairs; veins pilose abaxially, glabrescent adaxially, with only catenate-glandular hairs; laminar tissue between the veins abaxially with catenate-glandular hairs, adaxially glabrous; lamina margins glabrous; sori marginal; pseudoindusia glabrous or rarely with one or two cilia.

Specimens examined: Cachoeiro do Itapemirim, Vargem Alta, 24.VIII.1948, A.C. Brade 19355 (RB, SP).

Hypolepis rigescens var. rigescens is widespread in South America, plus Costa Rica and Panama (Prado et al. 2015; Schwartsburd \& Prado 2016). In the state of Espírito Santo it occurs at ca. 100-700 $\mathrm{m}$ a.s.1., in the mountains of quartz (Morros de Sal). The other variety, H. rigescens var. buchtienii (Rosenst.) Schwartsb., is endemic to Bolivia (Schwartsburd et al. unpublished data).

Hypolepis rigescens var. rigescens differs from the other aculeate species of Hypolepis from Espírito Santo by the glandular hairs present on all laminar axes and abaxially on the laminar tissue between the veins (Fig. 5a-c). The other species are eglandular.

\subsection{Hypolepis rugosula subsp. pradoana} Schwartsb., Kew Bull. 67(4): 818, Figs. 2a-e, 3c, d. 2012.

Fig. 5d-h

Plants terrestrial or epipetric. Rhizomes long-creeping with catenate-acicular hairs. Fronds determinate, erect to arched, (15-)60-140 cm long; petioles burgundy, rugose, inermous, villous 


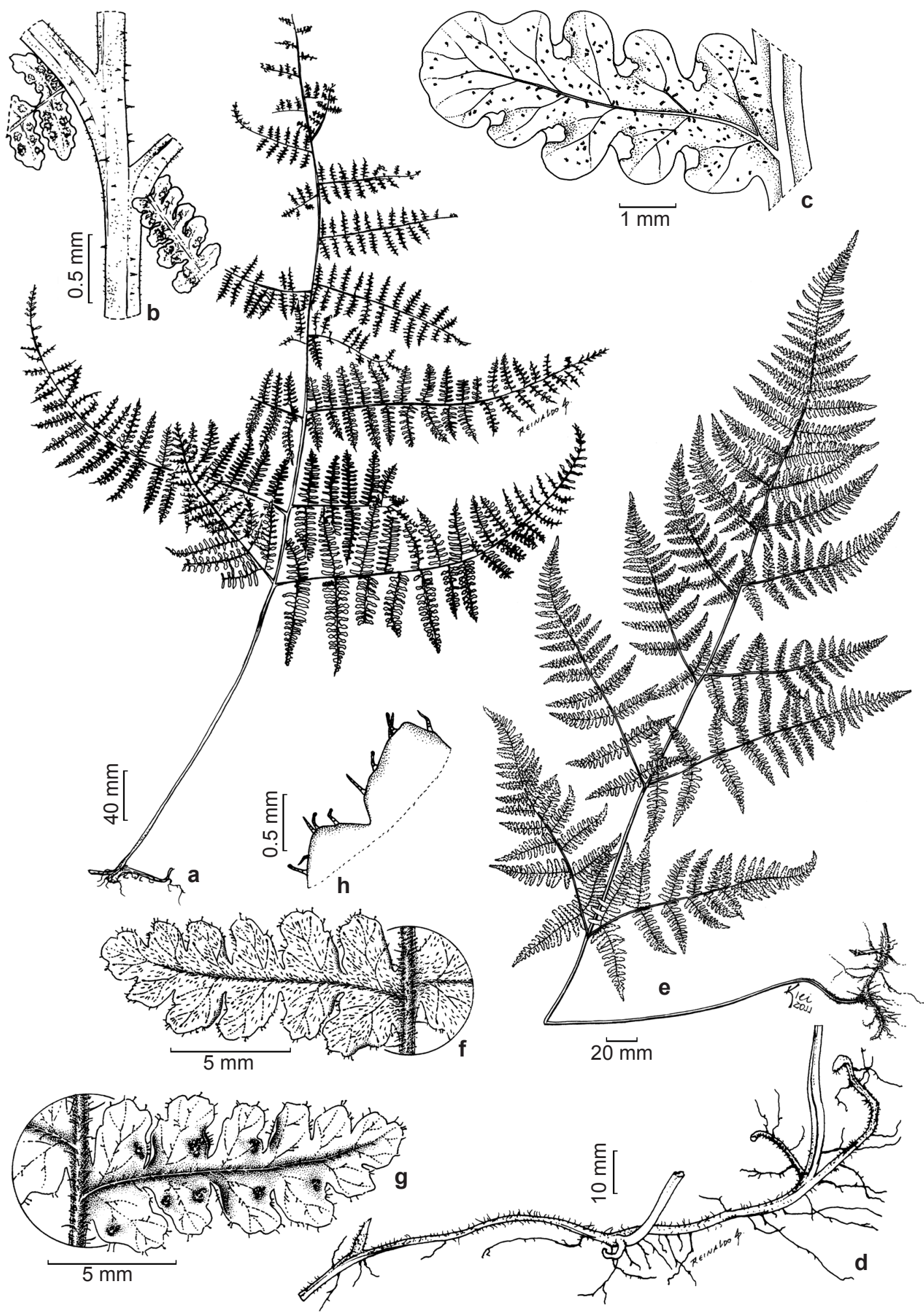

Figure 5 - a-c. Hypolepis rigescens var. rigescens - a. habit; b. intersection of petiole and rachis; c. segments, abaxiall). d-h. H. rugosula subsp. pradoana - d. rhizome; e. habit; f. pinnule, adaxially; g. pinnule, abaxially; h. detail of laminar margin (a. Rodríguez 4118; b. Méndez 71; c. Werff 3040; d. Becari-Viana 1; e. Schwartsburd 2310; f-h. Forzza 3412). 
abaxially and adaxially, with three kinds of hairs, catenate-acicular, catenate-glandular, and a few long catenate-acicular similar to those from the rhizomes; laminae bipinnate-pinnatifid to tripinnate-pinnatifid proximally; rachises straight, burgundy throughout, or burgundy proximally and stramineous above, rugose, inermous, the indument similar to the petioles; basal pinnae (2-)12-30 $\times$ (1.5-)4-12 cm, equilateral; costae villous abaxially and adaxially, with catenate-acicular and catenateglandular hairs; costules abaxially with catenateglandular hairs, adaxially with catenate-acicular and catenate-glandular hairs; veins with the same pattern of indument from costules; laminar tissue between the veins glabrous abaxially, adaxially with sparse catenate-acicular and catenate-glandular hairs; lamina margins with catenate-acicular and catenate-glandular hairs sparsely throughout; sori submarginal, unprotected or slightly protected; pseudoindusia absent, sometimes the lamina margins slightly revolute and protecting the sori, but never differentiated into thinner flaps.

Additional specimens examined: BRAZIL. MINAS GERAIS (in the border with ESPÍRITO SANTO): Alto Caparaó, Parque Nacional do Caparaó, Pico da Bandeira, 20²6'S, 41²4'W, 2600 m, 9.VII.2009, P.B. Schwartsburd et al. 2000 (SP, VIC).

The Hypolepis rugosula-complex was studied in detail by Schwartsburd \& Prado (2014) and Schwartsburd et al. (2016). These authors considered $H$. rugosula a sub-cosmopolitan species with primary circum-Antarctic distribution, and with 17 geographically isolated populations (which they named as subspecies). In the Brazilian Atlantic
Rainforest, H. rugosula subsp. pradoana occurs. In the state of Espírito Santo it occurs only at the highest elevations of Parque Estadual do Caparó (at $2600 \mathrm{~m}$ a.s.1.), in the altitudinal fields (Campos de Altitude) and cloud forests (Matas Nebulares).

Hypolepis rugosula subsp. pradoana is the only Hypolepis species of Espírito Santo with inermous, burgundy petioles and rachises, and unprotected sori (or slightly protected with unmodified laminar margins). It is also characterized by the glandular hairs throughout the fronds.

5. Pteridium Gled. ex Scop., Fl. Carniol.: 169. 1760, nom. cons.

Rhizomes long-creeping, with a polycyclic dictyostele, with ciliform hairs. Fronds determinate; petioles adaxially grooved, inermous; laminae tripinnate or more dissected; rachises straight or flexuous; basal pinnae commonly inequilateral; costae without decurrent adaxial wings; veins free; laminar indument of gnarled, acicular, ciliform, arachnoid, and/or catenate hairs; sori marginal, linear, continuous along segment margins and sinuses, protected by pseudoindusia, and also by vestigial true abaxial indusia; spores trilete.

Phylogenetic systematics papers point to two or three diploid species and two lineages of hybrids, but a total of ca. 20 morphotypes (subspecies or varieties) are recognized (e.g., Tryon 1941; Thomson 2008, 2012; Der et al. 2009; Schwartsburd et al. 2014, unpublished data; Wolf et al. 2015).

\section{Key to taxa of Pteridium from the state of Espírito Santo}

1. Simple distal segments to $1(-1.5) \mathrm{cm}$ long (Fig. 6f); veins abaxially with stiff, acicular hairs; laminar tissue between the veins abaxially with farinaceous appearance, fully covered by gnarled hairs (Fig. 6h) 5.2. Pteridium arachnoideum subsp. campestre

1'. Simple distal segments to 3(-4) cm long (Fig. 6b); veins abaxially with lax, arachnoid hairs; laminar tissue between the veins abaxially without farinaceous appearance, glabrous (Fig. 6d) 5.1. Pteridium arachnoideum subsp. arachnoideum

5.1. Pteridium arachnoideum (Kaulf.) Maxon subsp. arachnoideum, J. Wash. Acad. Sci. 14(4): 89. 1924. Pteris arachnoidea Kaulf., Enum. Fil. 190. 1824, nom. cons. Allosorus arachnoideus (Kaulf.) C.Presl, Tent. Pteridogr. 153. 1836, as “(Desv.) C.Presl”. Pteris aquilina var. arachnoidea (Kaulf.) D.C.Eaton, Mem. Amer. Acad. Arts Sci., n. ser., 8: 203. 1861. Cincinalis arachnoidea (Kaulf.) Trevis., Syll. Sporoph. Ital. 1: 31. 1874. Pteridium aquilinum var. esculentum f. arachnoideum (Kaulf.) Hieron., Hedwigia 48: 246. 1909. Pteridium aquilinum var. arachnoideum (Kaulf.) Brade, Deutsch. Verein Wiss. Kunst São Paulo 1: 56. 1920. Filix-foemina aquilina var. arachnoidea (Kaulf.) Farw., Amer. Midl. Naturalist 12(8): 290. 
1931. Pteridium caudatum subsp. arachnoideum (Kaulf.) Lellinger, Amer. Fern J. 93(3): 150. 2003. Pteridium esculentum subsp. arachnoideum (Kaulf.) Thomson, Telopea 14: 45. 2012.

Fig. 6a-d

Plants terrestrial, thicket forming. Rhizomes long-creeping, with ciliform hairs. Fronds determinate, erect to arched, (1.2-)2-3(-4.5) m long; petioles stramineous, glabrous; laminae proximally tripinnate-pinnatifid to tetrapinnatepinnatifid; pinnae and pinnules distally with free lobes between the segments; compound distal segments inequilateral, irregularly dissected, caudate at apex; simple distal segments linear, to $3(-4) \mathrm{cm}$ long; costae abaxially terete, with catenate hairs, adaxially glabrous; costules abaxially strongly flattened with wing-like appearance, with catenate hairs, adaxially glabrous; veins abaxially with lax arachnoid hairs, adaxially glabrous; laminar tissue between the veins abaxially without farinaceous appearance, glabrous and totally visible, adaxially glabrous; pseudoindusia generally glabrous or ciliate in young plants.

Specimens examined: Domingos Martins, 22.VI.2014, P.B. Schwartsburd \& J.H. Lima 3273 (VIC). Linhares, Comboios, 19.IX.1991, L. Behar \& G.M.F. Viégas 354 (VIC, VIES). Marechal Floriano, 20.4131 ${ }^{\circ} \mathrm{S}$, $40.6831^{\circ} \mathrm{W}, 700 \mathrm{~m}, 12 . \mathrm{VIII} .1988$, O.J. Pereira \& L. Behar 1629 (VIC, VIES). Santa Maria de Jetibá, $20^{\circ} 08^{\prime}$ 'S, $40^{\circ} 49^{\prime} \mathrm{W}, 6 . \mathrm{IX} .2008$, T.S. Lorencini et al. 49 (VIC, VIES). Santa Teresa, 17.V.1985, W. Boone 452 (MBML).

Additional specimens examined: BRAZIL. MINAS GERAIS [in the border with ESPÍRITO SANTO]: Alto Caparaó, Parque Nacional do Caparaó, trilha para o Pico da Bandeira, $2180 \mathrm{~m}, 9$.VII.2009, P.B. Schwartsburd et al. 2015 (VIC), $-20.4080^{\circ}$, $-41.8344^{\circ}, 1970 \mathrm{~m}, 11 . \mathrm{VII} .2009$, P.B. Schwartsburd

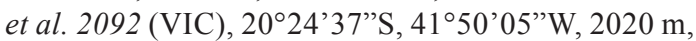
9.VII.2009, P.B. Schwartsburd et al. 2093 (VIC), P.B. Schwartsburd et al. 2094 (VIC).

The morphotypes of Pteridium arachnoideum have long been overlooked, until Schwartsburd et al. (2014) called the attention to the existence of two morphotypes in Eastern South America: P. arachnoideum subsp. arachnoideum and $P$. arachnoideum subsp. campestre. Schwartsburd et al. (unpubl. data) are further recognizing another four morphotypes for South America, and they are updating the geographical distribution of the former two. Pteridium arachnoideum subsp. arachnoideum is widespread in South America, with a preference for the Southern and Eastern parts. In the state of Espírito Santo it occurs from sea level to 2020 $\mathrm{m}$ a.s.l., in open places, disturbed areas, edges of forests, next to croplands, etc.

Pteridium arachnoideum subsp. arachnoideum differs from $P$. arachnoideum subsp. campestre by the characters shown in the key, plus longer fronds (2-3 m vs. 1-1.5 m long), irregular dissected, caudate compound distal segments ( $v s$. regularly dissected and not caudate), and different habitat (Figs. 6a-d vs. 6e-h).

\subsection{Pteridium arachnoideum subsp. campestre} (Schrad.) Schwartsb. \& P.L.R.Moraes in Schwartsb. et al., Phytotaxa 170(2): 111. 2014. Pteris campestris Schrad., Gott. Gel. Anz. 1824: 871. 1824.

Figs. 6e-h

Plants terrestrial, forming small tickets. Rhizomes long-creeping with ciliform hairs. Fronds determinate, erect to arched, 1-1.5(-2.0) $\mathrm{m}$ long; petioles stramineous, glabrous; laminae proximally tripinnate-pinnatifid; pinnae and pinnules distally without free lobes between the segments, with only decurrent lobes; compound distal segments equilateral, regularly dissected, not caudate; simple distal segments linear, to $1(-$ $1.5) \mathrm{cm}$ long; costae abaxially terete, with catenate hairs, adaxially glabrous; costules abaxially slightly flattened, with catenate hairs, adaxially glabrous; veins abaxially with stiff, acicular hairs, adaxially glabrous; laminar tissue between the veins abaxially with farinaceous appearance, not visible, totally covered by gnarled hairs, adaxially glabrous; pseudoindusia glabrous.

Specimens examined: Guarapari, $20.5774^{\circ} \mathrm{S}$, $40.4158^{\circ} \mathrm{W}, 16$. V.1988, L. Behar 76(VIES), 17.X.1988, L. Behar \& G.M.F. Viégas 223 (VIC, VIES), 18.III.1989, L. Behar 251 (VIC, VIES), Rodovia do Sol, Km 34, 11.VI.1989, L. Behar \& G.M.F. Viégas 257 (VIC, VIES), P.E. Paulo César Vinha, 31.IV.2007, M. Rossi $10 b$ (VIC, VIES). Vila Velha, Morada do Sol, $20^{\circ} 27^{\prime} 43^{\prime \prime} \mathrm{S}, 40^{\circ} 20^{\prime} 35^{\prime \prime} \mathrm{W}, 0-3 \mathrm{~m}, 12 . \mathrm{III} .2006$, P.F. Souza \& F.A.R. Matos 133 (MBML, VIC), entre Vila Velha e Ponta da Fruta, $20.4590^{\circ} \mathrm{S}, 40.3410^{\circ} \mathrm{W}, 10 \mathrm{~m}$, 30.IX.2016, P.B. Schwartsburd et al. 3785 (NY, UC, VIC), P.B. Schwartsburd et al. 3791 (VIC). Vitória, R.E. Restinga de Camburí, 23.XII.1997, A.M. Assis \& I. Weiler Jr. 341 (VIC, VIES).

Pteridium arachnoideum subsp. campestre occurs in South America, with a preference for the Northern and Northeastern parts (Schwartsburd et al. 2014, unpublished data). In the state of Espírito Santo it occurs at sea level, in the white sand forest (Restingas). 


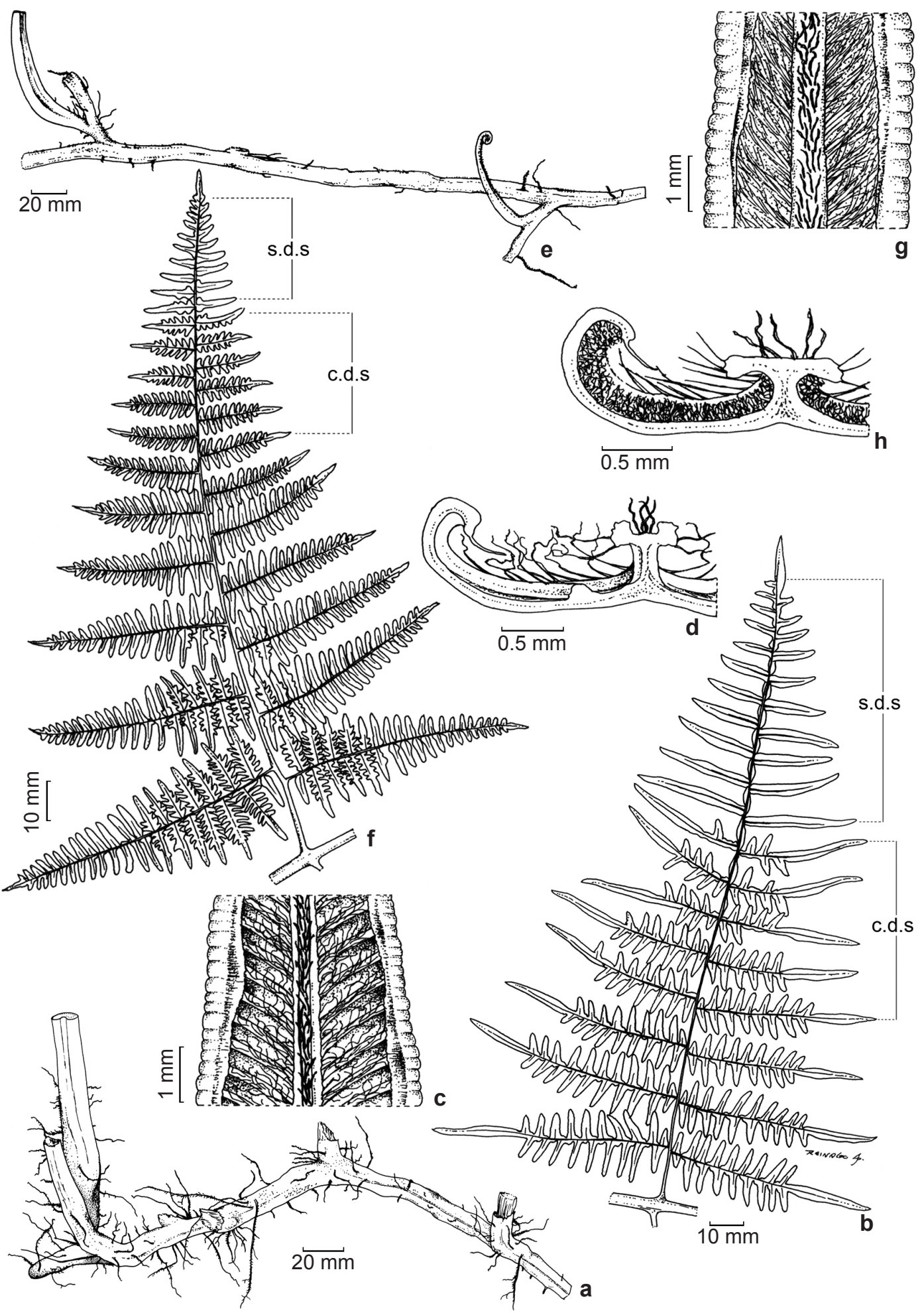

Figure 6 - a-d. Pteridium arachnoideum subsp. arachnoideum - a. rhizome; b. pinnule; c. segment, abaxially; d. segment in cross section. e-h. P. arachnoideum subsp. campestre - e. rhizome; f. pinnule; g. segment, abaxially; h. segment in cross section (a. Schwartsburd 2838; b-d. Schwartsburd 2490; e. Silva 1; f. Nonato 927; g, h Schwartsburd 2411). "c.d.s." - compound distal segments; "s.d.s." - simple distal segments. 


\section{Acknowledgements}

I thank the Curators and staff of herbaria CESJ, MBML, RB, UPCB, VIC, and VIES, R. Pinto and K. Souza for the illustrations, I. Becari-Viana, J. Bordin, J.H. Lima, R. Louzada, M.H. Oliveira, C.V. Miranda, M.R. Niedfeld, M. Nogueira Jr., N.T.L. Pena, J.B.S. Pereira, and R. Santana for helping in the field expeditions. I also thank A. Alves-Araújo, T. Carrijo, V.F. Dutra, L. Kollmann, and J.R.P.M. Oliveira for general support and invitation to participate on this project, and the handling editor (V.F. Dutra) and the two anonymous reviewers for their suggestions on the early version of this paper.

\section{References}

Assis FC \& Salino A (2011) Dennstaedtiaceae (Polypodiopsida) no estado de Minas Gerais, Brasil. Rodriguésia 62: 11-33.

Becari-Viana I \& Schwartsburd PB (2017) Morphoanatomical studies and evolutionary interpretations of the rhizomes of extant Dennstaedtiaceae. American Fern Journal 107: 105-123.

Der JP, Thomson JA, Stratford JK \& Wolf PG (2009) Global chloroplast phylogeny and biogeography of bracken (Pteridium, Dennstaedtiaceae). American Journal of Botany 96: 1041-1049.

Hojo-Souza NS, Carneiro CM \& Santos RC (2010) Pteridium aquilinum: o que sabemos e o que ainda falta saber? Bioscience Journal 26: 798-808.

Kramer KU (1990) Dennstaedtiaceae. In: Kramer KU \& Green PS (eds.) Pteridophytes and gymnosperms. In: K Kubitzki (general ed.). The families and genera of vascular plants. Springer-Verlag, Berlin. Pp. 81-94.

Mickel JT \& Smith AR (2004) The pteridophytes of Mexico. Memoirs of the New York Botanical Garden 88: 1-1055.

Navarrete H \& Øllgaard B (2000) The fern genus Dennstaedtia (Dennstaedtiaceae) in Ecuador - new characters, new species and a new combination. Nordic Journal of Botany 20: 319-346.

Perrie LR, Shepherd LD \& Brownsey PJ (2015) An expanded phylogeny of the Dennstaedtiaceae ferns: Oenotrichia falls within a non-monophyletic Dennstaedtia, and Saccoloma is polyphyletic. Australian Systematic Botany 28: 256-264.

PPG I - The Pteridophyte Phylogeny Group (2016) A community-derived classification for extant lycophytes and ferns. Journal of Systematics and Evolution 54: 563-603.

Prado J, Sylvestre LS, Labiak PH, Windisch PG, Salino A, Barros ICL, Hirai RY, Almeida TE, Santiago ACP, Kieling-Rubio MA, Pereira ANF, Øllgaard B, Ramos CGV, Mickel JT, Dittrich VAO, Mynssen
CM, Schwartsburd PB, Condack JPS, Pereira JBS \& Matos FB (2015) Diversity of ferns and lycophytes in Brazil. Rodriguésia 66: 1073-1083.

Schwartsburd PB (2010) Dennstaedtiaceae. In: Forzza RC et al. (orgs.) Catálogo de plantas e fungos do Brasil. Vol. 1. Jardim Botânico do Rio de Janeiro, Andrea Jakobsson Studio, Rio de Janeiro. Pp. 530-531.

Schwartsburd PB \& Prado J (2014). Subspecies of Hypolepis rugosula (Dennstaedtiaceae; Pteridophyta) around the world: morphological and biogeographic perspectives. Acta Botanica Brasilica 28: 206-226.

Schwartsburd PB \& Prado J (2015) A taxonomic revision of the South American species of Hypolepis (Dennstaedtiaceae), part I. American Fern Journal 105: 263-313.

Schwartsburd PB \& Prado J (2016) A taxonomic revision of the South American species of Hypolepis (Dennstaedtiaceae), part II. American Fern Journal 106: 1-53.

Schwartsburd PB, Moraes PLR \& Lopes-Mattos KLB (2014) Recognition of two morpho-types in eastern South American brackens (Pteridium - Dennstaedtiaceae - Polypodiopsida). Phytotaxa 170: 103-117.

Schwartsburd PB, Oliveira MH, Joner DC, Loyola R \& Prado J (2017) Additions to the taxonomy of the Hypolepis rugosula complex (Dennstaedtiaceae) in Africa: corrections, two new subspecies and new distribution maps. Folia Geobotanica 51: 373-381.

Smith AR, Pryer KM, Schuettpelz E, Korall P, Schneider H \& Wolf PG (2008) Fern classification. In: Ranker TA \& Haufler CH (eds.) Biology and evolution of ferns and lycophytes. Cambridge University Press, Cambridge. Pp. 417-467.

Thomson JA (2008) Morphotype and conflicting taxonomies in Pteridium (Dennstaedtiaceae: Pteridophyta). Fern Gazette 18: 101-109.

Thomson JA(2012) Taxonomic status of diploid southern hemisphere brackens (Pteridium: Dennstaedtiaceae). Telopea 14: 43-48.

Tryon RM (1941) Revision of the genus Pteridium. Contributions from the Gray Herbarium of Harvard University 134 reprint from Rhodora 43: 1-31, 37-67.

Tryon RM (1960) A review of the genus Dennstaedtia in America. Contributions from the Gray Herbarium of Harvard University 187: 23-52.

Tryon RM (1962) Taxonomic fern notes III. Contributions from the Gray Herbarium of Harvard University 191: 91-107.

Tryon RM \& Stolze RG (1989) Pteridophyta of Peru, part II: 13. Pteridaceae - 15. Dennstaedtiaceae. Fieldiana, Botany, new series 22: 1-128.

Tryon RM \& Tryon AF (1982) Ferns and allied plants, with special reference to Tropical America. SpringerVerlag, New York. 857p. 
Wolf PG (1995) Phylogenetic analyses of $r b c \mathrm{~L}$ and nuclear ribosomal RNA gene sequences in Dennstaedtiaceae. American Fern Journal 85: 306-327.
Wolf PG, Rowe CA, Der JP, Schilling MP, Visger CJ \& Thomson JA (2015) Origins and diversity of a cosmopolitan fern genus on an island archipelago. AoB Plants 7: plv118. 
